\title{
A Humanização como Parte do Ensino Aprendizagem de Saúde Bucal na Escola
}

\author{
Ikeda, Marlene Mieko Yamanaka; Beltrami, Maria Jose; Cunha, Cristina S. G. \\ Fernandes; Pereira, Beatriz \\ Centro de Saúde Escola Samuel Barnsley Pessoa - FMUSP — marleneikeda@usp.br
}

Introdução: a humanização é um tema frequente nos serviços públicos de saúde, sendo um instigante campo de inovação de produção teórica e prática na área da saúde. Participação, autonomia, responsabilidade são valores que caracterizam esse modo de fazer saúde, além de possibilitar escolhas mais conscientes e responsáveis. Dentro desse contexto, a equipe de saúde bucal de um centro de saúde da cidade de São Paulo vem experimentando novos percursos de ensino e aprendizagem em uma escola municipal da região, considerada um ambiente social propício à recepção de novos conhecimentos. Há três anos, a equipe realiza ações educativas e preventivas em saúde bucal, através de oficinas de alimentação, de doenças bucais, de escovação e de conhecimento prévio sobre saúde bucal com alunos da $4^{a}$ série do ensino fundamental desse espaço escolar. e desta forma, tem conseguido integração entre as equipes, alunos e professores, criação de espaço de conversas e troca de conhecimentos, de desenvolvimento de habilidades e práticas de autocuidado, estabelecendo um ambiente que apoie o esforço de cada um e do conjunto para ter uma rotina saudável. Objetivo: Convidar os alunos a visitar a Associação Paulista de Cirurgiões Dentistas (APCD) para conhecer o museu de odontologia e participar de uma atividade de prevenção em saúde bucal para complementar o aprendizado obtido nas oficinas, conferindo mais conhecimento, autonomia e responsabilidade com sua saúde bucal e geral. Método: Os alunos tiveram a oportunidade de assistir a um filme sobre saúde bucal, com orientações sobre higiene oral, dieta e as principais causas do aparecimento da cárie e gengivite, além de realizar na prática a escovação dentária e o uso correto do fio dental. Logo após, os alunos foram conhecer o museu de odontologia, sua história e os equipamentos odontológicos dos mais antigos até os mais modernos. no dia seguinte, os alunos escreveram e/ou ilustraram em uma folha de papel suas observações sobre o evento. Resultado: Pelos relatos obtidos, foi observado que houve participação ativa, rica e criativa de informações por parte dos alunos como verificado na escrita de alguns deles: "agradeço pela oportunidade de ir ao museu, ... gostei também dos ensinamentos, como usa a escova e como escovar os dentes para manterem limpos e saudáveis e branquinhos como nunca e meus pais terem orgulho de mim sempre"; e "gostei de ter a companhia da professora, das dentistas e, principalmente, dos meus colegas e gostei de aprender mais um pouco...". Conclusão: Proporcionar eventos diferenciados e criativos aos alunos, valoriza e reforça o que eles já sabem, e consequentemente, os estimulam a se interessarem por novos conhecimentos, auxiliando na reflexão e na formação de opiniões, demonstrando respeito e aumentando a estima e a autoconfiança.

Ikeda, Marlene Mieko Yamanaka; Beltrami, Maria Jose; Cunha, Cristina S. G. Fernandes; Pereira, Beatriz. A Humanização como Parte do Ensino Aprendizagem de Saúde Bucal na Escola. In: Anais do Congresso Internacional de Humanidades \& Humanização em Saúde [= Blucher Medical Proceedings, num.2, vol.1]. São Paulo: Editora Blucher, 2014. ISSN 2357-7282

DOI 10.5151/medpro-cihhs-10274 